\title{
Interplanting Crested Wheatgrass with Shrubs and Alfalfa: Effects of Competition and Preferential Clipping
}

\author{
BRUCE M. PENDERY AND FREDERICK D. PROVENZA
}

\begin{abstract}
Planting palatable shrubs and legumes into an established stand of crested wheatgrass (Agropyron desertorum and $A$. cristatum) could increase forage yield and nutritional quality. Preferential grazing of the grass and legume in spring may enhance establishment of shrub seedlings. Seedlings of 3 species of shrubs (A rtemisia tridentata ssp. vaseyana, Kochia prostrata, and Atriplex canescens) were transplanted into plots of crested wheatgrass using a replacement series design. Each species of shrub was grown with the grass, and with the grass and alfalia (Medicago sativa cv. 'Ladak'); each of the 5 species was also grown in monoculture. Swards were either uncut or the grass and alfalfa were clipped while actively growing in late May and early June. Shrubs had greater current annual growth $(C A G)(P \leq 0.001)$, higher relative yields $(P \leq 0.05)$, lower mortality $(P \leq 0.001)$, and more inflor escences $(P \leq 0.001)$ in monoculture than in mixture. The grass had greater CAG in mixture than in monoculture $(P \leq 0.05)$, and the grass and alfalfa had greater relative yield in mixture than in monoculture $(P \leq 0.05)$. Clipping crested wheatgrass and alfalfa increased shrub CAG $(P \leq 0.01)$, reduced mortality $(P \leq 0.001)$, and increased the number of inflorescences $(P \leq 0.01)$, but the increase in shrub CAG and flowering due to clipping was not as great as when shrubs were grown in monoculture. There were no interactions between competition and clipping $(P>0.05)$. In terms of $C A G$, mortality, and nowering, $A$. tridentata grew better than $K$. prostrata, which grew better than $A$. canescens, but these relationships involved complex interactions. The contribution of shrubs to the biomass in mixture was minor; although alfalin dominated three-way mixture yields, the grass also made a substantial contribution. Since competition was more important in determining shrub response than clipping and the 2 effects were independent, it is probably more important to reduce interspecific competition than to modify graxing practices when planting shrubs in a crested wheatgrass stand.
\end{abstract}

Key Words: plant interference, preferential grazing, range seeding, Agropyron desertorum, Medicago sativa, Artemisia tridentata, Kochin prostrata, Atriplex canescens.

Many native rangelands in the Intermountain area of the western United States were originally composed of mixtures of grasses, shrubs, and forbs. Overgrazing by livestock and suppression of fires at the beginning of this century led to domination by shrubs, particularly big sagebrush (Artemisia tridentata (Rydb.) (Laycock 1967, West 1983). To return these rangelands to a condition more suitable for livestock production, palatable and nutritious grasses, which are tolerant to grazing, were introduced from central Asia (West 1983). Of particular value were the crested wheatgrasses (Agropyron desertorum Fisch. ex (Link) Schult. and A. cristatum (L.) Gaertn.), and 5 million ha have been seeded to these species in

\footnotetext{
Authors are former graduate assistant and assistant professor, Department of Range Science, Utah State University, Logan, Utah. Pendery is currently a range scientist, USDA-ARS, Forage and Range Lab, Logan, Utah 84322-6300. Funding for this project was provided through Fund 779 of the Utah Agricultural Experiment Station. Published with the approval of the director, Utah Agricultural Experiment Station, Utah State University, Logan, Utah as Journal Paper Number 3236.

The authors would like to thank M.D. Rumbaugh, P.J. Umess, J.H. Richards. R.W. Snaydon, and 3 anonymous reviewers for suggestions for improving this manuscript. M. Mazurski drafted the figures, T.D. Smith typed the manuscript, and numerous people helped with fieldwork. We thank them ail.

Manuscript accepted 27 May 1987
}

the U.S. (Rogler and Lorenz 1983), often in monoculture.

Mixtures of species, however, may increase the quantity and nutritional quality of forage for livestock (Trenbath 1974, Gade and Provenza 1986). Palatable shrubs interplanted in established crested wheatgrass monocultures contain more protein than grass during winter, are less susceptible to trampling by livestock than grass, and stand above occasional deep snows (Gade and Provenza 1986). Mixtures of species could reduce the need for hay to feed livestock during winter, an expensive aspect of ranching in the Intermountain area. Furthermore, palatable legumes seeded into crested wheatgrass stands might increase soil nitrogen supply, increase forage protein content, and extend the grazing season further into the spring and early summer. Diversifying crested wheatgrass monocultures would also be beneficial for wildlife (McKell 1983).

Because crested wheatgrass provides valuable forage during spring and early summer, it might not be economically feasible or desirable to curtail grazing to permit establishment of interplanted shrub and forb seedlings. However, livestock and wild ungulates often preferentially graze grasses and forbs during spring (Laycock 1967, Smith and Doell 1968), which might reduce the establishment of interplanted legumes, but could aid shrub establishment by reducing competition from neighboring non-woody species.

The objective of this study was to investigate the effects of transplanting seedlings of several shrub species and alfalfa (Medicago sativa (L.) cv. 'Ladak') into an established stand of crested wheatgrass. The shrubs were mountain big sagebrush (Artemisia tridentata (Rydb.) ssp. vaseyana Beetle), forage kochia (Kochia prostrata (L.) Schrad.), and fourwing saltbush (Atriplex canescens (Pursh.) Nutt.). These species have been suggested for interseeding in crested wheatgrass stands (Stevens et al. 1981). Preferential grazing of the grass and alfalfa was simulated by clipping them in late May and early June, a common time for grazing crested wheatgrass.

\section{Methods and Materials}

\section{Study Site}

The study was conducted in 1983 and 1984 at the Green Canyon Ecology Center, $4 \mathrm{~km}$ northeast of Logan, Utah $(1,460 \mathrm{~m}$ elevation). The area was formerly occupied by bluebunch wheatgrass (Pseudoroegneria spicata (Pursh.) Löve) and big sagebrush, and is typical of areas seeded to crested wheatgrass (Hull and Hull 1974, Caldwell et al. 1981). Soils are rocky mollisols (typic haploxerolls) that formed on alluvial fan material (Southard et al. 1978). Precipitation at a weather station $1 \mathrm{~km}$ (same elevation) from the study site was $930 \mathrm{~mm}$ in 1983 and $646 \mathrm{~mm}$ in 1984, both above the long-term average of $468 \mathrm{~mm}$. Caldwell et al. (1981) provide further details of the climate at Green Canyon.

\section{Plant Materials}

The sources for plant materials were: (1) mature crested wheatgrass plants collected in an established ( 30 years) stand near Tintic, Utah; (2) certified Ladak alfalfa seed purchased commercially; (3) mountain big sagebrush seedlings collected near the study site; (4) forage kochia and fourwing saltbush seed collected from a nursery near Nephi, Utah. Tintic and Nephi are $200 \mathrm{~km}$ south of the study area. Plants were grown outdoors in tubepacks of $180 \mathrm{~cm}^{3}$ volume in 1982, and in the greenhouse during the winter and spring 1983. 
The soil used was an equal-parts mixture of soil obtained at the study site, a sandy-loam and peatmoss, and no fertilizer was added. All plants were placed outdoors for 2-3 weeks prior to transplanting as tublings.

\section{Experimental Design}

The experimental design consisted of 3 replications of a randomized complete block design with split-plots, and each whole-plot was $8 \mathrm{~m}$ square. There were 11 whole-plots per replication: 5 were monocultures (crested wheatgrass, alfalfa, big sagebrush, forage kochia, fourwing saltbush); $\mathbf{3}$ were two-way mixtures of the grass with 1 of the shrub species; and 3 were three-way mixtures of the grass, alfalfa, and 1 of the shrub species.

There were 289 plants/plot in monocultures and two-way mixtures and plants were spaced $0.5 \mathrm{~m}$ apart. Plants were planted in a checkerboard arrangement in two-way mixtures. There were 281 plants/plot in three-way mixtures. These plots had parallel, alternating rows of the 3 species that were oriented diagonally to the plot edges. Plants were spaced $0.56 \mathrm{~m}$ apart within diagonal rows and $0.5 \mathrm{~m}$ apart between rows.

The study site was plowed and disced in April 1982, and the downed weedy vegetation was left on site. Crested wheatgrass plants were transplanted with about $10,000 \mathrm{~cm}^{3}$ of soil while in the vegetative phenostage in May and June 1982, and they received about $300 \mathrm{~mm}$ of supplemental water to aid establishment. These plants were trimmed to a basal area of 150 to $200 \mathrm{~cm}^{2}$ in March 1983 to equalize initial sizes. Seedlings of shrubs and Rhizobiuminoculated alfalfa were transplanted in May of 1983, and an additional $300 \mathrm{~mm}$ of supplemental water was applied. Shrubs that died were replaced in June 1983 and April 1984. The shrubs varied in age from 6 months to about 1 year when planted, but all were 2 to 8 cm tall.

Each plot was divided into quarters and clipping treatments (spring or none) were randomly assigned to 2 of the subplots; 2 additional quarters are being used for other research. Grass plants were clipped to $5 \mathrm{~cm}$ height while in the boot stage between $28 \mathrm{May}$ and 4 June in 1983 and 1984 . Clipping removed apical meristems which were elevated above $5 \mathrm{~cm}$ by this time. Alfalfa was in the initial bloom stage when clipped. Clipping does not perfectly simulate grazing, and Norton and Johnson (1981) showed that under their experimental conditions, grazing of crested wheatgrass was less severe than the treatment we applied.

\section{Weight Estimates}

The biomass of grass and alfalfa was determined by clipping to 5 $\mathrm{cm}$ in the spring (see above) and at the end of the growing season (12-20 September) when the plants were essentially dormant. The herbage was dried at $60^{\circ} \mathrm{C}$ until weights were constant. Three, 5 , or 10 grass or alfalfa plants were sampled in three-way, two-way, and one-way mixtures, respectively, and only plants missing no more than one neighbor were sampled.

The weights of shrubs were estimated nondestructively using allometric regressions based on the relationship between shrub branch weight and shrub branch diameter. Correlations were high ( $r^{2}=0.91$ to 0.96 ) and significant ( $P \leq 0.001$ ) (Pendery 1985). Estimates were for 3,5 , or 10 shrubs in three-way, two-way, and one-way mixtures, respectively. Only shrubs planted in 1983 and missing no more than 1 neighboring plant were sampled. Dead shrubs were not sampled, but this information is in the survival data (see below).

Above-ground biomass of grass, alfalfa, and forage kochia was considered current annual growth (CAG). Both CAG and total standing crop of big sagebrush and fourwing saltbush were estimated (Pendery 1985), but because none of the interpretations differed, only CAG results are presented here. "Composite plant" weights were also determined, and these were calculated by summing the average weight of each of the components in a mixture, then dividing by the number of components $(1,2$, or 3$)$.

\section{The Yields}

Since the mixtures were a replacement series, Relative Yield Per Plant (RYP) and Relative Yield Total (RYT) were calculated as described by Fowler (1982). A RYP of 0.5 indicates that a species weighs $50 \%$ less per plant in mixture than it does in monoculture, and RYP has been considered a measure of the effects of interspecific competition. RYT is the average of RYP values for the components of a mixture and measures the degree of niche overlap between species (Fowler 1982) or the "combining ability" (Trenbath 1974) of species grown in mixture. A RYT of 1.5, for example, indicates the relative total biomass of a mixture is $50 \%$ greater than the relative biomass in monocultures. By definition, RYP and RYT are 1.0 in monoculture.

\section{Shrub Mortality and Reproductive Effort}

Mortality of shrubs was determined by censusing the plots between 28 September and 15 October 1984. Only shrubs planted in 1983 were included in this analysis. The number of branches with inflorescences were counted on shrubs that were sampled for weight estimates. Reproductive allocation is usually determined by weighing the reproductive structures, but we believe the number of inflorescences were well correlated with their weight, and other workers have used this technique as well (Silvertown 1982). Fourwing saltbush was not included in this analysis because none of the plants flowered.

\section{Data Andysis}

Data were analyzed by least squares analysis of variance (ANOVA). After averaging over subsamples, the data met the assumptions of ANOVA. The big sagebrush and forage kochia monocultures in the third replication could not be used because the plants were killed by a herbicide, dimethyl tetrachloroterephthalate, which was not applied to the other plots. As a result, the data were analyzed using RUMMAGE (Bryce 1980) because it is designed specifically for analyzing unbalanced data. Significant $(\alpha \leq 0.05)$ differences detected in the F-test were further analyzed by a least significant difference test (LSD.05).

Clipping effects on shrubs could only be analyzed for two- and three-way mixtures because the shrub monocultures were not clipped. The alfalfa RYP mixture versus monoculture comparison was made by constructing a $95 \%$ confidence interval around the three-way mixture mean. For the percent of shrubs dead, the analysis was of arcsine transformed data, but the results are presented as untransformed data.

\section{Results}

Data were collected in 1983 and in 1984 but only the 1984 results are reported here. In 1983 the plots were irrigated, there was confounding of transplanting and competition effects, and alfalfa plants were not clipped. Even so, the results in 1983 were similar to those in 1984 (Pendery 1985).

\section{Standing Crops}

Current annual growth of crested wheatgrass in monoculture was significantly $(P \leq 0.05)$ lower than that in mixture but grass weights in two- and three-way mixtures did not differ $(P>0.05)$ (Table 1). More specifically, CAG of grass in monoculture was less $(P \leq 0.05)$ than $C A G$ of grass when grown with big sagebrush or forage kochia, and when grown in three-way mixture with sagebrush (Fig. 1). Grass standing crop in two-way mixture with fourwing saltbush was less $(P \leq 0.05)$ than that in two-way mixture with big sagebrush or forage kochia (Fig. 1). Grass CAG in springclipped plots was significantly ( $P \leq 0.001$ ) lower than in unclipped plots (Table 1). The analysis did not detect significant differences in grass weights among the species of shrubs (Table 1), and no significant interactions were found.

Alfalfa CAG in three-way mixture did not differ $(P>0.05)$ from that in monoculture, nor did alfalfa weights differ $(P>0.05)$ when grown with the 3 species of shrubs (Table 1). Obviously, these data 
Table 1. Results of analyses in 1984 for oven-dry current annual growth (g/plant), relative yield per plant (RYP), mortality (percent), and flowering

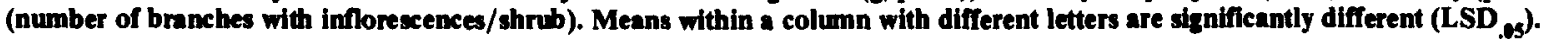

\begin{tabular}{|c|c|c|c|c|c|c|c|c|c|c|}
\hline \multirow[b]{2}{*}{ Source of Variation } & \multicolumn{4}{|c|}{ Current Annual Growth } & \multicolumn{4}{|c|}{ Relative Yield } & \multirow[b]{2}{*}{$\begin{array}{l}\text { Shrub } \\
\text { Morality }\end{array}$} & \multirow[b]{2}{*}{$\begin{array}{c}\text { Shrub } \\
\text { Flowe ring }\end{array}$} \\
\hline & Grass & Alfalfa & Shrub & $\begin{array}{l}\text { Composite } \\
\text { Plant }\end{array}$ & Grass & Alfalfa & Shrub & RYT $^{3}$ & & \\
\hline & & -8 & nt- & - &  & -RYP3 & 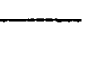 & & $-\%$ & $\begin{array}{l}\text {-No. Branches } \\
\text { w/Inflorescences- }\end{array}$ \\
\hline $\begin{array}{l}\text { Mixture Typel } \\
\text { Monoculture } \\
\text { Two-way } \\
\text { Three-way }\end{array}$ & $\begin{array}{l}49^{+} \\
90 a \\
78 a\end{array}$ & $\frac{79 a}{146 a}$ & $\begin{array}{r}58 \mathrm{a} \\
5 \mathrm{~b} \\
6 \mathrm{~b}\end{array}$ & $\begin{array}{l}59 a \\
48 a \\
78 b\end{array}$ & $\begin{array}{l}1.00 \mathrm{a} \\
1.89 \mathrm{~b} \\
1.66 \mathrm{~b}\end{array}$ & $\frac{1.00 \mathrm{a}}{2.20 \mathrm{~b}}$ & $\begin{array}{l}1.00 \mathrm{a} \\
0.07 \mathrm{~b} \\
0.12 \mathrm{~b}\end{array}$ & $\begin{array}{l}1.00 \mathrm{a} \\
1.08 \mathrm{a} \\
1.20 \mathrm{a}\end{array}$ & $\begin{array}{r}9 a \\
30 b \\
22 b\end{array}$ & $\begin{array}{r}31 \mathrm{a} \\
1 \mathrm{~b} \\
2 \mathrm{~b}\end{array}$ \\
\hline $\operatorname{LSD}_{.06}$ & 25 & 88 & $@$ & $@$ & 0.54 & 0.71 & 0.23 & 0.69 & $@$ & $2 @$ \\
\hline $\begin{array}{l}\text { Species of Shrubl } \\
\text { ARTR } \\
\text { KOPR } \\
\text { ATCA }\end{array}$ & $\begin{array}{l}97 a \\
90 a \\
65 a\end{array}$ & $\begin{array}{l}130 \mathrm{a} \\
144 \mathrm{a} \\
165 \mathrm{a}\end{array}$ & $\begin{array}{l}45 a \\
13 b \\
11 b\end{array}$ & $\begin{array}{l}85 a \\
52 b \\
47 b\end{array}$ & $\begin{array}{l}1.98 \mathrm{a} \\
2.01 \mathrm{a} \\
1.33 \mathrm{a}\end{array}$ & $\begin{array}{l}2.03 \mathrm{a} \\
2.22 \mathrm{a} \\
2.36 \mathrm{a}\end{array}$ & $\begin{array}{l}0.13 \mathrm{a} \\
0.13 \mathrm{a} \\
0.01 \mathrm{a}\end{array}$ & $\begin{array}{l}1.12 \mathrm{a} \\
1.35 \mathrm{a} \\
0.96 \mathrm{a}\end{array}$ & $\begin{array}{l}10 a \\
16 a \\
36 b\end{array}$ & $\begin{array}{r}13 a \\
10 b \\
0^{*}\end{array}$ \\
\hline LSD $_{06}$ & 33 & 88 & 4 & 14 & 0.70 & 1.91 & 0.24 & 0.71 & 11 & 2 \\
\hline $\begin{array}{l}\text { Season of Clipping }{ }^{2} \\
\text { Spring } \\
\text { No }\end{array}$ & $\begin{array}{r}55 a \\
102 b\end{array}$ & $\begin{array}{l}122 \mathrm{a} \\
136 \mathrm{a}\end{array}$ & $\begin{array}{l}9 \mathrm{a} \\
3 \mathrm{~b}\end{array}$ & $\begin{array}{l}52 \mathrm{a} \\
74 \mathrm{~b}\end{array}$ & $\begin{array}{l}1.97 \mathrm{a} \\
1.58 \mathrm{~b}\end{array}$ & $\begin{array}{l}2.60 \mathrm{a} \\
1.80 \mathrm{a}\end{array}$ & $\begin{array}{l}0.17 \mathrm{a} \\
0.01 \mathrm{a}\end{array}$ & $\begin{array}{l}1.32 \mathrm{a} \\
0.97 \mathrm{a}\end{array}$ & $\begin{array}{l}14 a \\
36 b\end{array}$ & $\begin{array}{c}3 \mathrm{a} \\
0.3 \mathrm{~b}\end{array}$ \\
\hline LSD $_{.05}$ & 18 & 43 & 4 & 15 & 0.37 & 1.62 & 0.17 & 0.55 & 19 & 2 \\
\hline
\end{tabular}

'Monocultures were crested wheatgrass, alfalfa, big sagebrush (ARTR), forage kochia (KOPR), and fourwing saltbush (ATCA). Two-way mixtures were crested wheatgrass and 1 of the species of shrubs. Three-way mixtures were the grass, alfalfa, and 1 of the species of shrubs.

2Only the grass and alfalfa were clipped.

${ }^{3}$ Relative Yield Per Plant (RYP) and Relative Yield Total (RYT). See Methods and Fowler (1982).

'Monoculture CAG differed $(P \leq 0.05)$ from the average yield in mixture $(84 \mathrm{~g} / \mathrm{plant}$, LSD $.06=31)$.

QData were unbalanced so LSD. .0 values vary. For shrub current annual growth, LSD .00 $=6$ for comparisons involving monocultures and 4 for comparison of 2 - and 3-way mixtures. For composite plants, $\mathrm{LSD}_{.06}=17$ for comparisons involving monocultures and 12 for comparison of 2-and 3-way mixtures. For mortality, $\mathrm{LSD} .06=13$ for comparisons involving monocultures and 9 for comparison of 2- and 3-way mixtures. For shrub flowering, LSD $06=2$ for all comparisons.

\&Ninety-five percent confidence interval of the 3-way mixture mean.

\#Fourwing saltbush plants did not flower and were not analyzed.

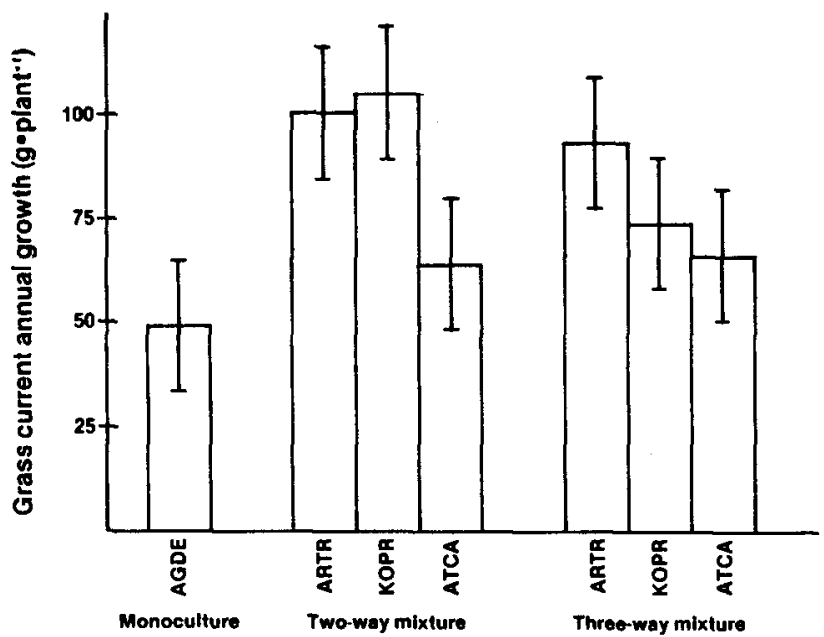

Fis. 1. Crested wheatgrass (AGDE) current annual growth in monoculture, and in two-and three-way mixtures when grown with mountain big sagebrush (ARTR), forage kochia (KOPR), and fourwing saltbush (ATCA), 1984. The third component of three-way mixtures was alfalfa (MESA). Error bars represent the LSD.06. All means are oven-dry weights.

were highly variable. Clipping in the spring versus not clipping did not significantly $(P>0.05)$ affect alfalfa $C A G$. Again, no significant interactions were detected.

Shrub CAG was significantly $(P \leq 0.001)$ greater in monoculture than in two- or three-way mixtures, and big sagebrush CAG was significantly ( $P \leq 0.001$ ) greater than forage kochia or fourwing saltbush CAG (Table 1). There was a significant $(P \leq 0.001)$ species of shrub by mixture type interaction for shrub CAG (Fig. 2). Shrub CAG in spring-clipped plots was significantly $(P \leq 0.01)$ greater than in plots in which the grass and alfalfa were not clipped (Table

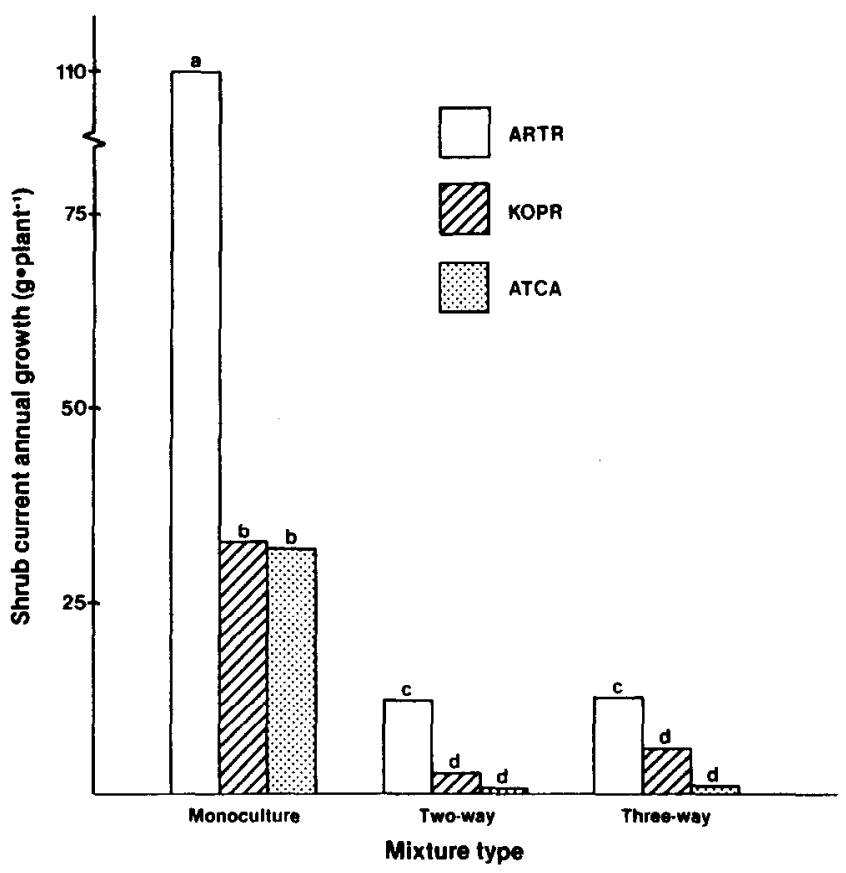

Fig. 2. Mountain big sagebrush (ARTR), forage kochia (KOPR), and fourwing saltbush (ATCA) current annual growth weights in monoculture, in two-way mixture with crested wheatgrass, and in three-way mixture with crested wheatgrass and alfalfa, 1984. Bars with different letters have significantly different means. The data were unbalanced; $L S D .05=10$ for comparisons involving big sagebrush or forage kochia monocultures, and $L S D_{.06}=6$ for all other comparisons. All means are oven-dry weights. 
1). The analysis did not detect significant interactions between clipping treatment and mixture type, clipping treatment and species of shrub, or a three-way interaction between the factors.

Composite plant weights differed $(P \leq 0.05)$ among the 9 treatments (Fig. 3). Mixture type and species of shrub were significant

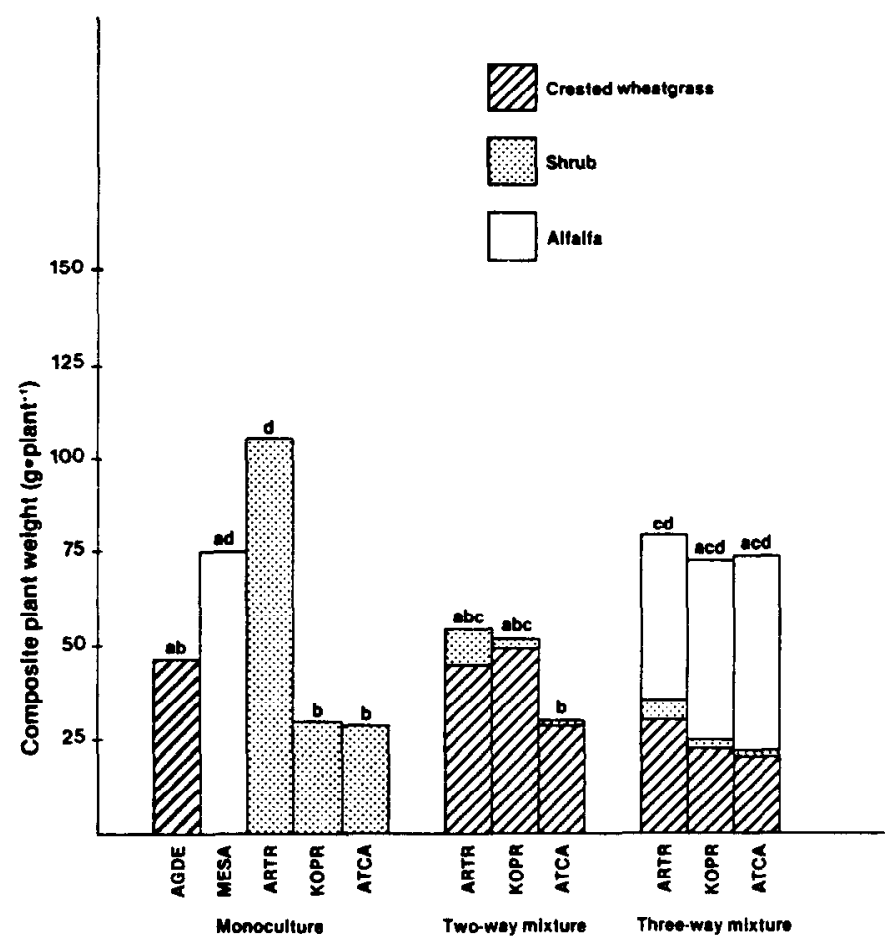

Fig. 3. Composite plant current annual growth weights among II treatments, 1984. The 5 species were grown in monoculture; the grass and each species of shrub were grown in two-way mixture; and the grass, alfalfa, and each species of shrub were grown in three-way mixture. See Figure 1 for species abbreviations. Bars with different letters have significantly different means. The data were unbalanced; $L S D_{.06}=40$ for comparison of big sagebrush and forage kochia monocultures; $L S D .06=$ 37 for other comparisons involving big sagebrush or forage kochia monocultures; and $L S D_{.06}=31$ for all other comparisons. The proportional contribution of the components (crested wheatgrass, shrub, alfalfa) of a composite plant are shown within each bar. All means are oven-dry weights.

$(P \leq 0.05)$ sources of variation within this treatment effect (Table 1). Grass monoculture weight $(49 \mathrm{~g} /$ plant) did not differ $(P>0.05)$ from the average composite plant weight of two- and three-way mixtures $(63 \mathrm{~g} /$ plant, LSD. $06=31)$. Clipping in the spring reduced $(P \leq 0.05)$ composite plant weights compared to unclipped plots (Table 1).

\section{Relative Yields}

Grass RYP in two-and three-way mixtures was greater $(P \leq 0.05)$ than in monoculture, but the mixtures did not differ $(P>0.05)$ from each other (Table 1). Grass RYP in spring-clipped plots exceeded $(P \leq 0.05)$ RYP in unclipped plots, which is the opposite of the effect of clipping on grass CAG weights (Table 1). The analysis did not detect differences $(P>0.05)$ in grass RYP among species of shrubs (Table 1), nor did significant interactions exist.

Alfalfa RYP in three-way mixture exceeded $(P \leq 0.05)$ that in monoculture (Table 1). Alfalfa RYP did not differ $(P>0.05)$ among species of shrubs or clipping treatments (Table 1). Significant interactions were not found.

Shrub RYP in two- and three-way mixtures was significantly $(P \leq 0.05$ ) less than 1.0, but RYP did not differ between mixtures $(P>0.05)$. Unlike shrub CAG weights, shrub RYP did not vary
( $P>0.05$ ) among species of shrubs (Table 1), nor was there a significant $(P>0.05)$ interaction between species of shrubs and mixture types. The effect of clipping on shrub RYP was not significant $(P>0.05)$ (Table 1), and there were no interactions between clipping treatment and mixture type, clipping treatment and species of shrub, or a three-way interaction among the factors.

RYT did not differ $(P>0.05)$ among mixture types, species or shrubs, or clipping treatments (Table 1). No interactions were detected in the RYT data $(P>0.05)$.

\section{Shrub Mortality and Reproductive Effort}

Shrub mortality was lower $(P \leq 0.001)$ in monoculture than in two- or three-way mixtures (Table 1). Mortality of fourwing saltbush was higher $(P \leq 0.001)$ than for big sagebrush or forage kochia, and clipping the grass and alfalfa in the spring reduced $(P \leq 0.005)$ shrub mortality compared to not clipping (Table 1$)$. No significant interactions were detected.

The number of branches with inflorescences per shrub differed $(P \leq 0.001)$ among mixture types and species of shrubs (Table $l$ ), and there was also a significant $(P \leq 0.001)$ mixture type by species of shrub interaction (Fig. 4). Clipping the grass and alfalfa in the



Fig. 4. Mountain big sagebrush (ARTR) and forage kochia (KOPR)flowering (number of branches with inflorescences/plant) in monoculture, in two-way mixture with crested wheatgrass, and in three-way mixture with crested wheatgrass and alfalfa, 1984. Bars with different letters have significantly different means. The data were unbalanced; $L S D_{.05}=4$ for comparison of monocultures; $L S D_{.05}=3$ for other comparisons.

spring increased $(P \leq 0.01)$ the number of branches per shrub with inflorescences compared to shrubs in unclipped plots (Table 1). The analysis did not detect any other significant differences.

\section{Discussion}

\section{Competition Effects \\ Response of the Shrubs}

The most striking conclusion from this study was that competition from an already established stand of large crested wheatgrass plants greatly reduced the absolute and relative biomass (Table 1, Fig. 2), survival (Table 1), and flowering (Table 1, Fig. 4) of interplanted shrub seedlings compared to monocultures of shrubs. The shrubs in monoculture were planted into plots that had been fallow for 1 year while the shrubs in mixtures were planted into plots where, presumably, the established grass had utilized soil 
water and nutrients, precluding their use by the shrubs.

Several previous studies have shown that the first plants to become established have an advantage over later-arriving neighbors and that large size also confers a competitive advantage to a plant. Blaisdell (1949) found that grasses seeded 2 years prior to seeding big sagebrush dramatically suppressed sagebrush standing crop for at least 5 years. Peterson et al. (1986) reported that the survival and size of fourwing saltbush seedlings transplanted into already established stands of sideoats grama (Bouteloua curtipendula) were reduced due to competition from the grass. Sideoats grama is a warm-season rhizomatous species, while crested wheatgrass is a cool-season bunchgrass. Other reports (e.g., Grubb 1977, Snaydon and Howe 1986) show similar responses when plants are seeded or transplanted into an established sward, and also have shown that: (1) seeding places a plant at even more of a competitive disadvantage than does transplanting, and (2) most competition occurred below ground. In addition to occupying the plots first, crested wheatgrass initially had a tremendous (at least $50 \mathrm{X}$ ) size advantage over the shrubs and alfalfa. Size may also confer a competitive advantage to a plant (Harper 1977), although there is some evidence to the contrary (Newberry and Newman 1978).

While the grass was only planted 1 year before the shrubs, its establishment was enhanced by watering throughout 1982. This allowed the plants to grow all summer and fall. Also, decomposing vegetation resulting from preparing the site for planting could have contributed nutrients to the grass, further increasing its degree of establishment.

\section{Response of Alfalfa}

Although being in competition with the previously established and larger grass was a disadvantage for the shrubs, the alfalfa overcame the competitive advantage given to the grass in mixtures (Table 1). After 2 growing seasons, alfalfa in mixture weighed 146 $\mathrm{g} /$ plant while the grass weighed $78 \mathrm{~g}$ /plant in three-way mixture. Unlike the shrubs, alfalfa plants were relatively smaller in monoculture than in mixture, implying intraspecific competition was more of a factor for alfalfa than for the shrubs. Unfortunately, we did not grow the grass and alfalfa in two-way mixture.

\section{Reasons for Differential Responses of Shrubs and Alfalfa}

Alfalfa could have overcome the competitive advantages given to crested wheatgrass while the shrubs did not because alfalfa can fix nitrogen. Large nodules were present on the alfalfa, but we did not quantify numbers, size, or activity. Under tropical conditions, established grasses are more sensitive to competition from oversown legumes than from oversown grasses, implying competition for nitrogen is important (Cook 1980, Cook and Dolby 1981). Because water was relatively abundant during our study, competition for a resource other than water may have been important.

A second reason that alfalfa may Have done well in mixture while the shrubs did not is that high intrinsic growth rates are characteristic of species, such as alfalfa, adapted to productive environments, while slow growth rates are typical of species, such as the shrubs, adapted to less productive environments (Grime and Hunt 1975, Coley et al. 1985). Species with slow intrinsic growth rates grow slowly even in favorable environments (Coley et al. 1985), and the abundance of moisture during our study created relatively favorable conditions. Further, species with high growth rates but small size, in this case alfalfa, may be able to overcome competition from large plants with relatively slow growth rates, such as the grass (Newberry and Newman 1978).

A third reason that alfalfa grew bigger than the shrubs could relate to differences in rooting patterns relative to the grass. Alfalfa seedlings are aggressive compared to grasses because of the development of a deep taproot (Chamblee 1972). Caldwell and Richards (1986) reported that in mixture, crested wheatgrass roots dominated big sagebrush roots in the $20-50 \mathrm{~cm}$ depth and the big sagebrush dominated at greater depths, although the rooting density for both species was low below $50 \mathrm{~cm}$. Forage kochia has a taproot that extends to at least $3.5 \mathrm{~m}$ depth and it has many auxiliary branches, particuarly in the upper $40 \mathrm{~cm}$ of soil (Balyan 1972). Wallace et al. (1980) reported that $76 \%$ of the root mass of fourwing saltbush was located in the upper $50 \mathrm{~cm}$ of a soil with a caliche layer. Neither kochia nor fourwing saltbush rooting patterns have been studied when growing with crested wheatgrass, and the root development of seedlings of the 3 shrub species compared to grasses have not been reported.

\section{Clipping Effects \\ Responses of the Shrubs}

A second major conclusion from our research was that clipping of associated grass and alfalfa plants increased shrub CAG, survival, and flowering (Table 1), but that clipping had less effect than competition on shrub CAG and flowering (Table 1, Figs. 2 and 4). This conclusion is evident when shrub monocultures, which were not clipped and did not have a previously established competitor, are considered. For example, sagebrush in mixtures weighed about $12 \mathrm{~g} /$ plant while sagebrush in monoculture weighed $110 \mathrm{~g} / \mathrm{plant}$ (Fig. 2), a much greater effect than that produced by clipping ( 9 vs. $3 \mathrm{~g}$ / plant, Table 1). However, if only the mixtures are considered, the largest difference between shrub weights (sagebrush in threeway mixture vs. fourwing saltbush in two-way mixture) is 11 $\mathrm{g} /$ plant (Fig. 2), which is more comparable to the difference produced by clipping ( $6 \mathrm{~g} /$ plant). The more nearly equal impact of these factors on shrubs in mixtures is surprising given the competitiveness of crested wheatgrass and alfalfa (Caldwell et al. 1985, Chamblee 1972, Dubbs 1971), their tolerance of clipping (Caldwell et al. 1981, Chamblee 1972), and the advantage of prior establishment given the grass. The effects of clipping and competition on shrub mortality were comparable (Table 1).

Previous work also shows that preferential grazing of grasses and forbs in the spring favors shrub growth (Laycock 1967, Smith and Doell 1968), and other reports also show that competition affects grass and forb weights and reproduction more than either preferential or direct clipping (Mueggler 1972, Cook 1984, Fowler and Rausher 1985). However, Parker and Salzman (1985), working with snakeweed (Gutierrezia microcephala) seedlings in New Mexico found that direct herbivory had a greater effect than competition on survivorship, that competition and herbivory had about equal impacts on growth, and that both factors also strongly influenced flowering.

\section{Responses of Grass and Alfalfa}

The effects of clipping on grass weights were paradoxical. Removal of apical meristems by clipping in the spring created smaller plants on an absolute basis but they had a higher RYP than unclipped grasses (Table 1). Clipping probably reduced competition among crested wheatgrass plants in mixtures, assuming the shrubs offered no substantial competition(Figs. 2 and 3). Unclipped crested wheatgrass plants continued to compete relatively more than clipped plants, probably due to uncurtailed root growth (Richards 1984). Also, clipping crested wheatgrass in the spring stimulates tillering (Caldwell et al. 1981), which might increase the relative ability of a plant to compete despite being smaller (Newberry and Newman 1978). This is especially likely because water was abundant during our study, so regrowth was relatively uninhibited (see Blaisdell and Pechanec 1949). Alfalfa showed the same absolute and relative responses to clipping as the grass (Table 1), but these differences were not significant.

\section{Clipping and Competition Interaction Effects}

There were no significant interactions between clipping and competition in two- and three-way mixtures relative to shrub biomass, mortality, or flowering. Also, neither the grass nor alfalfa CAG analyses showed a significant interaction between clipping and the competitive environment. The independence of these 2 effects seems counterintuitive and we are at a loss to explain it. Unlke our findings for shrubs, Fowler and Rausher (1985) found that Texas Dutchman's pipevine (Aristolochia reticulata) shoot and 
reproductive mass was affected jointly by clipping of little bluestem (Schizachrium scoparium) and the presence or absence of southern dewberry (Rubus trivialis), but their treatments were not exactly analogous to ours. When the effects of direct clipping on Aristolochia were considered, Fowler and Rausher did not find an interaction between clipping and competition, which is similar to our findings for the grass and alfalfa. Parker and Salzman (1985) likewise reported no significant interaction for plant growth, but did report a significant interaction for survival. Since competition was more important than clipping in determining shrub responses in our experiment, and the effects were independent, it is probably more important to reduce interspecific competition than to modify grazing practices when planting shrubs in a crested wheatgrass stand. In particular, planting small patches of shrubs, rather than interplanting, should be studied.

\section{Performance of the Shrubs}

Under the conditions of our study, and based on above-ground measurements, mountain big sagebrush performed better than forage kochia and kochia performed better than fourwing saltbush. While previously established crested wheatgrass had no more relative effect on sagebrush than it did on kochia or fourwing saltbush (Table 1), sagebrush was either able to capture more resources than the other 2 species, utilize them more efficiently, or both, particularly in monoculture (Table 1, Fig. 2). The success of sagebrush compared to kochia and fourwing saltbush was also indicated by its high survival and flowering, although kochia did as well as sagebrush in terms of survival, and in terms of flowering in two- and three-way mixtures (Table 1, Fig. 4). Fourwing saltbush consistently grew more poorly than sagebrush, and was less successful than kochia in terms of survival and flowering.

The replacement series design, coupled with analysis of plant weights on a relative basis, has often been used as a measure of the effects of interspecific competition (e.g., Fowler 1982). However, this method has been criticized recently because the multidimensional nature of mixtures is reduced to 1 dimension, density is chosen arbitra rily, and several causes for differences in observed versus expected yields are possible, but not uniquely identifiable (Conolly 1986). These criticisms have some validity, so some would argue that the greater success of sagebrush compared to kochia, and of kochia compared to fourwing saltbush, should be viewed as experiment-specific and not necessarily universal; however, we have based this conclusion on several responses, not just relative yields. Also, additive designs may simulate interplanting into an established sward better than replacement series designs (Snaydon and Howe 1986), but they are not without difficulties because the effects of density and frequency are confounded (Silvertown 1982).

\section{Yield Relationships}

The contribution of shrubs to composite plant weights in mixtures was minor; crested wheatgrass dominated in two-way mixtures and alfalfa dominated three-way mixtures (Fig. 3). Crested wheatgrass did not respond as favorably to association with fourwing saltbush as reported by Rumbaugh et al. (1982) (Fig. 1 and 3). Any response due to fourwing saltbush seems unlikely, however, because the plants were so small (Figs. 2 and 3 ). The grass also did not respond negatively to association with big sagebrush, as has often been reported (e.g., Hull and Klomp 1974) (Figs. 1 and 3). This probably reflected the advantages of prior establishment and larger initial size given the grass. Forage kochia-Agropyron and kochia-Agropyron-alfalfa mixtures have been reported to produce more forage than kochia monocultures (Balyan 1972). Our results indicated no particular advantage of kochia-grass mixtures, but kochia-grass-alfalfa mixtures had greater CAG than kochia monocultures (Fig. 3). In a Montana study in which the species were seeded concurrently, alfalfa weights in mixture exceeded crested wheatgrass weights (Dubbs 1971), as did the alfalfa CAG in our study (Fig. 3). However, the relative contribution of grass and alfalfa in a mixture is quite variable (see Chamblee 1972).
In general, three-way mixtures show some promise of producing more total forage than crested wheatgrass monocultures but the shrubs may make little contribution, at least after the first 2 growing seasons (Fig. 3). Two-way mixtures show little promise of increasing forage yields over crested wheatgrass monocultures (Fig. 3), but they could have nutritional benefits (Gade and Provenza 1986). RYT values did not differ significantly among mixture types although there was an increase between monocultures and three-way mixtures (Table 1). Trenbath (1974) reported that "overyielding" (i.e., RYT significantly $>1.0$ ) is rare in agronomic and pasture studies unless a legume is included in a mixture, so it is not surprising that RYT in two-way mixture did not differ from 1.0. RYT for three-way mixtures was more surprising since a legume was included in the mixtures, and perhaps significant differences will develop over time.

\section{Literature Cited}

Balyan, G.A. 1972. Prostrate summer cypress and its culture in Kirghizia. Nat. Tech. Inform. Ser. TT77-59026, Nat. Sci. Found., Washington, D.C.

Blaisdell, J.P. 1949. Competition between sagebrush seedlings and reseeded grasses. Ecology 30:512-519.

Blaisdell, J.P., and J.F. Pechanec. 1949. Effects of herbage removal at various dates on vigor of bluebunch wheatgrass a nd arrowleaf balsamroot. Ecology 30:298-305.

Bryce, G.R. 1980. Data analysis Rummage-A user's guide. Brigham Young Univ., Provo, Utah.

Caldwell, M.M., J.H. Richards, D.A. Johnson, R.S. Nowak, and R.S. Dzurec. 1981. Coping with herbivory: photosynthetic capacity and resource allocation in 2 semiarid Agropyron bunchgrasses. Oecologia 50:14-24.

Caldwell, M.M., D.M. Eissenstat, J.H. Richards, and M.F. Allen. 1985. Competition for phosphorus: differential uptake from duel-isotopelabled soil interspaces between shrub and grass. Science 229:384-386.

Caldwell, M.M., and J.H. Richards. 1986. Competing root systems: morphology and models of absorption, p. 251-273. In: T.J. Givnish (ed.), On the Economy of Plant Form and Function. Cambridge Univ. Press.

Chamblee, D.S. 1972. Relationships with other species in a mixture, p. 211-228. In: C.H. Hanson (ed.), Alfalfa Science and Technology. Amer. Soc. Agron., Madison, Wis.

Coley, P.D., J.P. Bryant, and F.S. Chapin, III. 1985. Resource availability and plant antiherbivore defense. Science 230:895-899.

Conolly, J. 1986. On difficulties with replacement-series methodology in mixture experiments. J. Appl. Ecol. 23:125-137.

Cook, S.J. 1980. Establishing pasture species in existing swards: a review. Trop. Grass1. 14:181-187.

Cook, S.J. 1984. Establishment of 4 pasture grasses and Siratro from seed oversown into dense and open speargrass pastures. Aust. J. Exp. Agr. Anim. Husband. 24:360-369.

Cook, S.J., and G.R. Dolby. 1981. Establishment of buffel grass, green panic, and Siratro from seed broadcast into a speargrass pasture in southern Queensland. Aust. J. Agr. Res. 32:749-759.

Dubbs, A.L. 1971. Competition between grass and legume species on dryland. Agron. J. 63:359-362.

Fowler, N. 1982. Competition and coexistence in a North Carolina grassland III: mixtures of component species. J. Ecol. 70:77-92.

Fowler, N.L., and M.D. Rausher. 1985. Joint effects of competitors and herbivores on growth and reproduction in Aristolochia reticulata. Ecology $66: 1580-1587$.

Gade, A.E., and F.D. Provenza. 1986. Nutrition of sheep grazing crested wheatgrass versus crested wheatgrass-shrub pastures during winter. J. Range Manage. 39:527-530.

Grime, J.P., and R. Hunt. 1975. Relative growth-rate: its range and adaptive significance in a local flora. $J$. Ecol. 63:393-422.

Grubb, P.J. 1977. The maintenance of species-richness in plant communities: the importance of the regeneration niche. Biol. Rev. 52:107-145.

Harper, J.L. 1977. Population biology of plants. Academic Press, London.

Hull, A.C., Jr., and M.K. Hull. 1974. Presettlement vegetation of Cache Valley, Utah and Idaho. J. Range Manage. 27:27-29.

Hull, A.C., Jr., and G.J. Klomp. 1974. Yield of crested wheatgrass under 4 densities of big sagebrush in southern Idaho. USDA Agr. Res. Serv. Tech. Bull. No. 1483.

Laycock, W.A. 1967. How heavy grazing and protection affect sagebrushgrass ranges. J. Range Manage. 20:206-213. 
McKell, C.M. 1983. The role of shrubs in diversifying a crested wheatgrass monoculture, p. 109-115. In: K.L. Johnson (ed.), Crested WheatgrassIts Values, Problems, and Myths. Symposium Proc., Utah State Univ., Logan.

Mueggler, W.F. 1972. Influence of competition on the responses of bluebunch wheatgrass to clipping. J. Range Manage. 25:88-92.

Newberry, D. McC. and E.I. Newman. 1978. Competition between grassland plants of different initial sizes. Oecologia 33:361-380.

Norton, B.E., and P.S. Johnson. 1981. Pattern of defoliation by cattle grazing crested wheatgrass pastures, p. 462-464. In: Proc. XIV Int. Grassl. Congr., Lexington, Ky.

Parker, M.A., and A.G. Salzman. 1985. Herbivore exclosure and competitor removal: effects on juvenile survivorship and growth in the shrub Gutierrezia microcephala. J. Ecol. 73:903-913.

Pendery, B.M. 1985. Simulated interplanting of crested wheatgrass with shrubs and alfalfa: effects of interference and preferential clipping. M.S. Thesis, Utah St. Univ., Logan.

Petersen, J.L., D.N. Ueckert, and R.L. Potter. 1986. Cultural practices for establishing fourwing saltbush within perennial grass stands. J. Range Manage. 39:460-463.

Richards, J.H. 1984. Root growth response to defoliation in two Agropyron bunchgrasses: field observations with an improved root periscope. Oecologia 64:2l-25.

Rogler, G.A., and R.J. Lorenz. 1983. Crested wheatgrass-early history in the United States. J. Range Manage. 36:91-93.
Rumbaugh, M.D., D.A. Johnson, and G.A. Van Epps. 1982. Forage yield and quality in a Great Basin shrub, grass, and legume pasture experiment. J. Range Manage. 35:604-609.

Silvertown, J.W. 1982. Introduction to plant population ecology. Longman Group Ltd., New York.

Smith, A.D., and D.D. Doell. 1968. Guides to allocating forage between cattle and big game on big game winter range. Utah State Div. Fish Game Pub. 68-11.

Snaydon, R.W., and C.D. Howe. 1986. Root and shoot competition between established ryegrass and invading grass seedlings. J. Appl. Ecol. 23:667-674.

Southard, A.R., L. Wilson, and A.J. Erickson. 1978. Chemical and physical properties of the soils of the Cache Valley area and the eastern portion of Box Elder County, Utah. Utah Agr. Exp. Sta. Res. Rep. 31.

Stevens, R., W.L. Moden, Jr., and D.W. Mckenzie. 1981. Interseeding and transplanting shrubs and forbs in grass communities. Rangelands 3:55-58.

Trenbath, B.R. 1974. Biomass productivity of mixtures. Adv. Agron. 26:177-210.

Wallace, A., E.M. Romney, and J.W. Cha. 1980. Depth distribution of roots of some perennial plants in the Nevada Test Site area of the northern Mojave Desert. Great Basin Natur. Memoirs 4:201-207.

West, N.E. 1983. Great Basin-Colorado Plateau sa gebrush semidesert; and Western Intermountain sagebrush steppe, p. 331-374. In: N.E. West (ed.), Temperate Deserts and Semi-Deserts. Elsevier Sci. Publ. Co., Amsterdam. 